\title{
Social and pedagogical competence of experts of the social sphere
}

Seryakova S. B., doctor of pedagogical sciences, professor, MPSU, Russia

At the first stage of the study, a conceptua model of socio-pedagogical competence was developed and, on its basis, a formalised psychogram was created. The image of the world was singled out as an opportunity for a specialist to model the development of the social sphere and to predict personal, professional development and evolution of the sphere of professional activity. The characteristics and level of development of professional competencies, professionally important knowledge and the ability to apply them are effectively addressed in the focus of professional success of a social professional. The structure of the psychogram includes the characteristics of adaptability, level of intelligence, personal characteristics. Experimental groups were formed and pilot studies were conducted. The materials obtained confirmed the assumptions made at the theoretical level and allowed us to create a theoretical, conceptual model of sociopedagogical competence and a formalized profile of the psychographic matrix

At the second stage of the study, the theoretical, conceptual model served as the basis for the selection of diagnostic material for large-scale research and the creation of the operant model of the social and pedagogical competence of a socia specialist. The results showed that the main function-determining components of the operant model of socio-pedagogical competence are:

1) the level of adaptability, as a fundamenta characteristic of the subject's ability to interact with the environment and
2) the personal level, which determines the ability of the social sphere specialist to see their personal and professional future. The structure-determining component distinguished the level of development of the intellect, which determined the strategy and tactics for solving by a specialist both global tasks of personal growth and tactical tasks of professional activity.

The data obtained during the empirical study with the participation of a representative research group allowed us to conclude that there is a fixed statistical relationship between the level of intelligence development, professional success and the complex characteristic of the development of a person's cognitive sphere, cognitive strategy in solving professional problems (design thinking).
At the third stage of the study, an empirical test of the effectiveness of the operant mode of the social and pedagogical competence of a social specialist was conducted. A comparative analysis of the level of success of social professionals, the characteristics and level of formation of social and pedagogical competence was conducted. The study permeated the participation of a group of professionals working in different organizations.

In the course of the study, developed methodological materials can be used in the development programmes of employees of the organisation from the stage of adaptation development, inclusion in the personne reserve until the completion of professional activities, which will most effectively realise the potential of each social sector specialist.
The developed material is aimed at the formation of an individual cognitive strategy for solving professional tasks. In the course of summarizing the results, methodological recommendations were developed on the selection of diagnostic tools and drawing up a career planning program for social professionals. The development and assessment of the socio-pedagogical competence of a specialist is the need to make a forecast of the further development of professionally important qualities.

The scientific novelty of the study lies in the prognostic orientation of the created model of social and pedagogical competence of a social sphere specialist. This opens up opportunities for further research and the transfer of the basic principles of creating an operant model of competence in different professional fields.
Operant model of social-pedagogical competence of a specialist in the social sphere

\begin{tabular}{|l|l|l|}
\hline & $\begin{array}{l}\text { The future inage is the vision what } \\
\text { a specialist in the social sphere } \\
\text { expects from lis professional and } \\
\text { personal futture }\end{array}$ & \\
\hline $\begin{array}{l}\text { Strategyldesign of thinking of a } \\
\text { specialist with a low intelligence } \\
\text { level }\end{array}$ & $\begin{array}{l}\text { Strategyldesign of thinking of a } \\
\text { specialist with an average intelligence } \\
\text { level }\end{array}$ & $\begin{array}{l}\text { Strategyldesign of thinking of a } \\
\text { specialist with a superior intelligence } \\
\text { level }\end{array}$ \\
\hline $\begin{array}{l}\text { Desire to emphasise the soft nature of } \\
\text { character. }\end{array}$ & $\begin{array}{l}\text { Desire to express suspicion, conflict, } \\
\text { emotional immaturity and lack of } \\
\text { criticism of their condition. Women } \\
\text { have a tendency to show } \\
\text { determination and masculinity as well } \\
\text { as difficulties in interpersonal } \\
\text { communication. }\end{array}$ & $\begin{array}{l}\text { Desire to express anxiety, } \\
\text { interpersonal difficulties and mood } \\
\text { swings. High introversion rates. }\end{array}$ \\
\hline & Intelligence level & \\
\hline & Adaptability & \\
\hline
\end{tabular}

